\title{
RECOGNITION AND ENFORCEMENT OF FOREIGN JUDGMENTS: A NEW APPROACH FOR THE HAGUE CONFERENCE?
}

\author{
ARTHUR T. VON MEHREN*
}

Since this article was originally written and presented in the spring of 1992, considerable progress has been made in the effort to achieve an international convention regulating jurisdiction and recognition of foreign judgments. In May 1993, the Seventeenth Session of the Hague Conference on Private International Law decided "to include in the agenda for work of the Conference the question of the recognition and enforcement of foreign judgments in civil and commercial matters" and requested the Conference's Secretary General to convene a Special Commission to "study[] further the problems involved in drafting a new convention," to "make[] proposals with respect to work which might be undertaken," and to "suggest [] the timing of such work."

The Special Commission met in the Hague on June 20-24, 1994, to begin this preliminary work on a convention. Our hope is that the Conference's Eighteenth Session in 1996 will make a convention on jurisdiction and recognition an agenda item for an extraordinary session of the Conference in 1997 or 1998.

The article was revised in May 1994 to take into account these and other developments since the spring of 1992. Its intention remains the same, however: to discuss the genesis of what is now the Hague jurisdiction and recognition project, to consider the merits and demerits of various approaches to jurisdiction and recognition problems, and to explain why, in the United States's view, the most promising institutional basis for achieving a satisfactory convention was the Hague Conference on Private International Law.

\section{INTRODUCTION}

The U.S. delegation to the June 1992 Meeting of the Special Commission on General Affairs and Policy of the Hague Conference on Private International Law proposed that the Conference undertake work on a convention dealing with the recognition and enforcement of foreign judgments. The proposal was

Copyright 101994 by Law and Contemporary Problems

* Story Professor of Law, Emeritus, Harvard University.

1. Hague Conference on Private International Law: Final Act, May 29, 1993 (Final Edition, Seventeenth Sess. 1993). 
received with interest. After considerable discussion, the Special Commission decided that the matter should be considered by a small Working Group. The Working Group, which was composed of experts from nine countries, met in the Hague on October 29, 1992, ${ }^{2}$ and discussed the following questions: Is the proposed topic an appropriate one for the Conference to take up? If so, what are the advantages of an approach in the form of a convention dealing only with recognition and enforcement (a convention simple ${ }^{3}$ ), as compared with a convention that addresses not only recognition and enforcement but also the assumption of jurisdiction to adjudicate (a convention double)? Or would-as the United States proposed to the Special Commission-a mixed form (a convention mixte), incorporating elements of both a convention simple and a convention double be preferable?

The Working Group's charge was to assist the Seventeenth Session of the Conference, held in May 1993, in reaching a decision as to whether the subject-in what form and with what priority-would be placed on the Conference's agenda of future work. The Working Group's conclusions, as drawn up by the Conference's Permanent Bureau, ${ }^{4}$ indicated "unanimous[] agree[ment] on the desirability of attempting to negotiate through the Hague Conference a new general convention on jurisdiction and recognition and enforcement of judgments." "The Working Group expressed a preference for the convention mixte approach, ${ }^{6}$ and agreed "that negotiating [such] a convention ... although not an easy matter, seemed to be technically feasible."

In order to assist the Working Group in its deliberations, the United States prepared a paper discussing the topic in general as well as the U.S. proposal for a mixed convention; to this paper was appended a draft skeleton convention illustrating the general form that a mixed convention might take. To avoid the possibility of prejudicing decisions that were for the Conference to make, the draft did not go into details, even for illustrative purposes, on such issues as what grounds for jurisdiction should be included in the convention's approved list.

The U.S. State Department's decision, in the Spring of 1992, to encourage new work by the Hague Conference on recognition and enforcement of judgments was made after the possibility of direct negotiations on this subject between the United States and the European Community-European Free Trade

2. The countries represented were Argentina, China, Egypt, Finland, France, Hungary, the United Kingdom, the United States, and Venezuela. The experts from the United States were Peter D. Trooboff, Peter H. Pfund, and Arthur T. von Mehren.

3. This expression can be translated into English as a "simple" or a "single" convention. The latter formulation is used by the Conference's Permanent Bureau. As neither formulation is current in English, the French expression is used in this article.

4. Permanent Bureau, Hague Conference on Private international Law: General AFFAIRS (Preliminary Doc. No. 19, Aug. 1992) (for the attention of the Seventeenth Session).

5. Id. at 17 .

6. Id. at 3-7.

7. Id. at 17 . 
Area ("EC-EFTA") countries had been explored. Recourse to the Conference seemed more attractive to the State Department than negotiations with the ECEFTA group on three scores: First, the Conference's Secretariat was interested in the topic; second, the Conference provides excellent preparatory and logistical support; and, third, perhaps most importantly, in Conference negotiations the United States would not face alone a group of European countries which-through the Brussels and Lugano Conventions-have committed themselves to positions respecting assumption of jurisdiction and enforcement of judgments that, although appropriate between and among nations integrating various sectors of their economies and societies, may not be appropriate for countries that are less closely linked economically, geographically, and politically.

Part II of this article addresses previous U.S. and European experiences respecting treaty regulation of the recognition and enforcement problem. Part III discusses the rationales for U.S. negotiation of a judgments treaty and the mechanisms through which such a treaty could be negotiated. Finally, Part IV outlines the advantages and disadvantages of conventions simples, doubles, and mixtes.

\section{A Glance at the ExPerience of the United States AND of EUROPEAN COUNTRIES}

\section{A. U.S. Experience with Recognition and Enforcement Treaties}

Traditionally, the United States has relied on judicially developed rules in according recognition and enforcement to foreign judgments. In contrast to Europe and, to a lesser extent, Latin America, the United States has rarely used its treaty-making power to handle recognition and enforcement problems. ${ }^{8}$ Explanations for this include the federal nature of the U.S. legal order and the traditional sensibilities of the states regarding local control of the administration of justice.

After the Second World War, however, a notable change took place in the U.S. political climate with respect to federal control over such matters as the recognition and enforcement of foreign judgments. On October 15, 1964, the United States became a member of the Hague Conference on Private International Law. A number of important conventions adopted by the Conference have since been ratified by the United States. In 1970, the United States took another important, and for it unprecedented, step of ratifying a major multilateral international recognition convention, the 1958 United Nations

8. The U.S. Department of State had declined as early as 1874 to use the treaty-making power in the area of private international law and the recognition and enforcement of judgments. See David Luther Woodward, Reciprocal Recognition and Enforcement of Civil Judgments in the United States, the United Kingdom and the European Economic Community, 8 N.C. J. INT'L L. \& COM. REG. 299,310 (1983). 
Convention on the Recognition and Enforcement of Foreign Arbitral Awards. ${ }^{9}$ A few years later, the United States and the United Kingdom entered into bilateral negotiations for a Convention on the Reciprocal Recognition and Enforcement of Judgments in Civil Matters. An ad referendum text was initialed in $1976,{ }^{10}$ and further negotiations in 1978 resulted in agreement ad referendum on modifications to the 1976 draft. $^{11}$

Negotiations between the United States and the United Kingdom had sought to take into account U.K. concerns about U.S. practices respecting such matters as punitive and multiple damages, and, more generally, the perception that damage awards given in the United States were, on occasion, considerably higher than damage awards given in the United Kingdom in generally comparable situations. Accordingly, the Convention was not to apply to judgments "to the extent they are for punitive or multiple damages." 12 The 1978 negotiations added a new Article 8A, which provided that

[w] here the respondent establishes that the amount awarded by the court of origin is greatly in excess of the amount, including costs, that would have been awarded on the basis of the findings of law and fact established in the court of origin, had the assessment of that amount been a matter for the court addressed that court may, to the extent then permitted by the law generally applicable in that court to the recognition and enforcement of foreign judgments, recognize and enforce the judgment in a lesser amount. ${ }^{13}$

In 1980, despite U.S. efforts to allay U.K. concerns, the negotiations broke down, due in large measure to the concerns respecting product liability held by U.K. manufacturers and the U.K. insurance industry; in a sense, they preferred the devil they knew to the one they did not. ${ }^{14}$

\section{B. European Experience with Recognition and Enforcement Treaties}

Unlike the United States, European and Latin American countries have for decades looked to international conventions as an important source of the law on the recognition and enforcement of foreign judgments. ${ }^{15}$ By the 1930s, not only civil law jurisdictions such as France but also a common law jurisdiction, the United Kingdom, had concluded numerous bilateral treaties regulating

9. June 20, 1958, 23 U.S.T. 2517,330 U.N.T.S. 3 (entered into force with respect to the United States, Dec. 29, 1970).

10. Convention on the Reciprocal Recognition and Enforcement of Judgments in Civil Matters, initialed Oct. 26, 1976, U.S.-U.K., 16 I.L.M. 71 [hereinafter Reciprocal Recognition Convention]. The author of the present article and the late Ambassador Richard D. Kearney were the principal U.S. negotiators.

11. For a convenient look at the differences between the 1976 and 1978 texts, see Woodward, supra note 8 , at $322-34$.

12. Reciprocal Recognition Convention, supra note 10, art. 2(2)(b), 16 I.L.M. at 73.

13. Woodward, supra note 8 , at 327.

14. See Peter M. North, The Draft U.K./U.S. Judgments Convention: A British Viewpoint, 1 Nw. J. INT'L L. \& BUS. 219, 223, 238 (1979); Arthur T. von Mehren, Recognition and Enforcement of SisterState Judgments: Reflections on General Theory and Current Practice in the European Economic Community and the United States, 81 CoLuM. L. Rev. 1044, 1060 n.61 (1981).

15. Georges Droz, Regards sur le droit international privé comparé, 229 RECUEIL DES COURS D'ACADÉmIE DE DROIT INTERNATIONAL 9, 100-09 (1991). 
recognition and enforcement practices. For the most part, ${ }^{16}$ multilateral conventions first became important for the recognition and enforcement problem after the Second World War. In 1971, the Hague Conference on Private International Law completed work on a Convention on the Recognition and Enforcement of Foreign Judgments in Civil and Commercial Matters. ${ }^{17}$ The Convention combines bilateral and multilateral elements; it was negotiated multilaterally, but was to come into force bilaterally. The Convention's failure to gain acceptance is likely attributable to the completion in 1968 of the European Economic Community Convention on Jurisdiction and Enforcement of Judgments in Civil and Commercial Matters. ${ }^{18}$ The Brussels convention naturally commanded the allegiance of the then-six Community states, which had prepared it in the belief that the ideal of the European Community would be furthered by facilitating the enforcement of judgments among its members.

As the Community grew in size and importance, the territorial scope and legal significance of the Brussels Convention increased. ${ }^{19}$ By the $1980 \mathrm{~s}$, economic and legal integration within the European Community had progressed to the point that several European countries that were not members became interested in concluding a recognition and enforcement convention with the member states as a group. Although in many cases bilateral treaties already existed between these states and EC members, ${ }^{20}$ it was thought that a generally accepted European regime for recognition and enforcement purposes would create a "European judicial area," thus simplifying and expediting the recognition and enforcement of judgments.

On September 16, 1988, the member states of the European Community and the European Free Trade Association concluded a Jurisdiction and Enforcement

16. A few, quite general provisions respecting recognition and enforcement of foreign judgments are contained in Latin American multilateral conventions negotiated between 1889 and 1940. 2 UNITED NATIONS, REgISTER OF TEXTS OF CONVENTIONS AND OTHER INSTRUMENTS CONCERNING INTERNATIONAL TRADE 5-7, 21-23, 18-20 (1973) (containing the English translations of the relevant provisions of the following conventions: The Treaty Concerning the Union of South American States in Respect of Procedural Law (1889 Montevideo Treaty; six states are parties); the Treaty on International Procedural Law (1940 Montevideo Treaty; three states are parties); and the Convention on Private International Law (1928 Bustamente Code; fifteen states are parties)).

17. Convention on the Recognition and Enforcement of Foreign Judgments in Civil and Commercial Matters, Feb. 1, 1971, 1144 U.N.T.S. 249 [hereinafter Hague Recognition Convention]. Having been signed by Cyprus, The Netherlands, and Portugal, the Convention has technically entered into force. However, it is not in effect because the aforesaid states have not concluded the required bilateral agreements, nor are they likely to do so.

18. Convention Concerning Judicial Competence and the Execution of Decisions in Civil and Commercial Matters, Sept. 27, 1968, 1262 U.N.T.S. 153 [hereinafter Brussels Convention]. Negotiations for the Convention began in 1959. The Convention entered into force in 1973 for the original contracting States (Belgium, France, Federal Republic of Germany, Italy, Luxembourg, and the Netherlands).

19. The original text has been amended three times: first, by the Convention of October 9, 1978, on the accession of Denmark, Ireland, and the United Kingdom; second, by the Convention of October 25,1982 , on the accession of Greece; and third by the Convention of May 26, 1989, on the accession of Spain and Portugal.

20. For a list of bilateral treaties, see Article 55 of Convention of Jurisdiction and the Enforcement of Judgments in Civil and Commercial Matters, Sept. 16, 1988, 1988 O.J. (L319) 9 [hereinafter Lugano Convention] (entered into force Jan. 1, 1992). 
convention in Lugano, ${ }^{21}$ which accepts the general approach of the Brussels Convention. The Lugano Convention does not, of course, displace the Brussels Convention with regard to relations inter se of the EC member states. The Lugano Convention applies rather to relations between EC and EFTA countries, and among EFTA countries. Recognition and enforcement problems arising among a large number of European states are now regulated by the essentially parallel provisions of either the Brussels or Lugano Conventions. Comparable language in the two Conventions may, however, on occasion not be uniformly interpreted and applied; for purposes of the Lugano Convention, national courts outside the EC are not bound to accept the interpretations given by the Court of Justice of the EC to parallel provisions in the Brussels Convention.

These developments have created a basically uniform European regime for the recognition and enforcement of judgments rendered in Europe. Resting on international agreements, the system is, by its nature, reciprocal. Negotiation of such a regime would not have been possible if each state had acted separately. Multilateral negotiations preceding the Brussels Convention occurred within a legal and political context such that the participating states ultimately had little choice but to accept the result. Thereafter, as the EC expanded, new member states were in the same position, although minor alterations to cure special problems resulting from the particularities of the new EC members states' laws were possible.

The position of the EFTA member states was similar. If they wanted a judgments convention with the EC member states, they had to accept the provisions of the Brussels Convention. The $\mathrm{EC}$ was not under pressure to agree to a substantively different treaty regime covering EFTA judgments. Had the Brussels Convention not been acceptable to the EFTA member states, the status quo would have continued.

\section{III}

\section{PROSPECTS FOR U.S. NEGOTIATION OF A JUDGMENTS CONVENTION}

This brief history suggests both that the United States may be interested in entering into treaty arrangements concerning the recognition and enforcement of foreign judgments, ${ }^{22}$ and that the obstacles that must be overcome in negotiating such treaties are considerable. Against these background propositions, three topics are discussed. First, what advantages would result from using treaties to regulate a substantial segment of the recognition and enforcement practice involving the United States? Second, are there any

21. Id.

22. A further motive for U.S. interest in treaty regulation of these matters is to remove discriminatory practices respecting the assumption of jurisdiction that were provided for by the Brussels Convention for suits brought against a defendant not domiciled in a contracting state, see von Mehren, supra note 14, at 1058-60, and are now a feature of the Lugano Convention as well. The relevant provisions of the Lugano Convention are discussed infra text accompanying notes 39-40; see also infra note 25 and accompanying text. 
mechanisms through which such treaties could be negotiated on a multilateral basis, or is bilateral negotiation alone feasible? Third, what is the likelihood that bilateral negotiations or, if feasible, multilateral negotiations could be brought to successful conclusions?

To assess the advantages of regulating by treaty a substantial segment of the recognition and enforcement practice involving the United States, one needs a basic understanding of the current situation. The position of the holder of a foreign judgment who wishes to enforce it in the United States is first considered. Where foreign judgments are at issue, each state remains, barring federal preemption, free to apply its own law respecting recognition and enforcement. Unlike sister-state judgments, foreign judgments are not covered by the Full Faith and Credit Clause of the Constitution of the United States. ${ }^{23}$ An element of federal oversight exists, however, under the Due Process Clause of the Fourteenth Amendment. ${ }^{24}$ Recognition and enforcement will be denied on due process grounds to foreign judgments that rest on unreasonable jurisdictional bases or that resulted from egregiously defective procedures. ${ }^{25}$

States are largely free to decide for themselves the effects that are to be accorded foreign adjudications. Subject only to due process, each state determines what jurisdictional test, if any, such a judgment must satisfy, the scope of review to be undertaken of the judicial process that produced the judgment in question, whether choice of law tests or reciprocity requirements are to be imposed, and whether révision au fond (review on the merits) is to be undertaken.

Despite the substantial freedom that states have enjoyed in the recognition and enforcement of foreign judgments, there is a strong-though by no means universal-tendency to give to such judgments the substantial preclusive effects that sister-state judgments enjoy under the Full Faith and Credit Clause. ${ }^{26}$ In particular, choice-of-law tests and reciprocity requirements are usually not imposed, and révision au fond usually is not undertaken. Moreover, for recognition and enforcement purposes, the jurisdictional requirement is usually taken to be satisfied, provided that the judgment does not rest on a jurisdictional basis that violates the minimum due process standard imposed in the recognition of sister-state judgments under the Full Faith and Credit Clause.

23. U.S. CONST. art. IV, $\S 1$, cl. 1 ("Full Faith and Credit shall be given in each State to the public Acts, Records, and judicial proceedings of every other State . . ..").

24. Id. amend. XIV, $\S 1$ ("[N]or shall any State deprive any person of life, liberty, or property, without due process of law ....").

25. The expression "exorbitant" to describe bases thought to be unreasonable is frequently encountered in discussions of the Brussels and Lugano Conventions.

26. See RESTATEMENT (SECOND) OF CONFLICT OF LAWS § $98 \mathrm{cmt}$. b (1971), which states: Judgments rendered in a foreign nation are not entitled to the protection of full faith and credit. In most respects, however, such judgments . . . will be accorded the same degree of recognition to which sister State judgments are entitled. This is because the public interest requires that there be an end of litigation .... 
Foreign judgments seeking recognition and enforcement in the United States are thus, on the whole, in a relatively favorable position; they will usually be recognized unless infected by a serious procedural defect or based on an exorbitant jurisdictional claim. Only a few states impose a reciprocity requirement or a choice of law test. From the perspective of the holder of a foreign judgment, the principal shortcoming of this scheme is that the law of recognition and enforcement varies in significant details from state to state. ${ }^{27}$ Accordingly, until the state in which recognition and enforcement will be sought is known, it may be difficult to determine how to enforce a foreign judgment in the United States and what precise effects the judgment will be given.

The recognition and enforcement problem is far more difficult and problematic when viewed from the perspective of the holder of a U.S. judgment who wishes to enforce it abroad. In many countries, substantially less preclusive effect is accorded U.S. judgments than would be available to a comparable foreign judgment in the United States. U.S. judgments abroad encounter reciprocity requirements ${ }^{28}$ and are subject to the imposition of choice of law tests and révision au fond.

\section{A. Advantages of a Recognition and Enforcement Convention}

Treaty arrangements in the recognition and enforcement field could be helpful to all concerned parties in three principal ways. ${ }^{29}$ First, a convention would ensure a rough equality between the practices of the contracting states. Attaining such equality, in view of the relatively generous practices of U.S. courts, would be of greater significance for the United States than for most of its treaty partners. Nevertheless, the international order as a whole would be served by establishing relatively uniform practices respecting the recognition and enforcement of judgments.

Second, a recognition and enforcement convention could deal with the regrettable practice, originated by the Brussels Convention and given further scope through the Lugano Convention, of permitting the use of unreasonable or exorbitant jurisdictional bases against persons not domiciled in a contracting state, and requiring that other contracting states recognize and enforce any resulting judgment. ${ }^{30}$ The proper solution to this lamentable situation would be for all states in their recognition practice to take the view embodied in the

27. One commentator remarks that there is "no 'American rule' for the recognition and enforcement of foreign judgments, but rather a crazy quilt arrangement of methods for their domestication." Woodward, supra note 8 , at 305.

28. The reciprocity requirements may be hard to satisfy, due to the difficulty of establishing definitively recognition practice that rests largely on case law rather than statute. See supra notes 22-23 and accompanying text.

29. Additional benefits would result if the recognition convention also dealt with the assumption of jurisdiction by the state of origin.

30. The Supreme Court of the United States has held that an "exorbitant" jurisdictional basis-service of process on a person while present in the jurisdiction-is constitutionally acceptable. Burnham v. Superior Court, 495 U.S. 604 (1990). No constitutional objection exists, however, to the United States accepting a treaty obligation not to assert jurisdiction on this basis in litigation with international dimensions. 
Constitution of the United States: that due process-natural justice-precludes the use of exorbitant jurisdictional bases against all defendants regardless of their nationality, domicile, or residence, and requires that enforcement be refused to foreign judgments resting on exorbitant jurisdictional bases. Accordingly, every contemporary judgment convention should include provisions ensuring results consistent with due process in situations with which, in view of the defendants' habitual residence, nationality, or otherwise, a contracting state is legitimately concerned.

Third, treaty regulation would clarify and simplify recognition and enforcement practices and procedures. As a result, a party holding a judgment rendered in, or contemplating initiating litigation in, a contracting state could ascertain relatively quickly and easily the effects that another contracting state would accord if recognition or enforcement were sought in its courts.

\section{B. The Several Approaches the United States Could Take in an Effort to Negotiate a Judgments Convention}

In concluding judgment conventions, the United States faces a particular difficulty. Producing a reasonably comprehensive judgments regime through bilateral negotiation would take decades. Moreover, unless each bilateral treaty conformed to the same model, the resulting regime would lack unity.

For large states, such as the United States, bilateral arrangements are most feasible with other states of relatively equal size and economic importance. For example, the day may come when bilateral negotiations between the United States and a true European federation would be feasible. Today, however, member states of the European Union do not recognize constitutional authority in any institution of the Union or the EC to conclude international arrangements respecting recognition practice that would be binding upon the Union as a whole. Under the EC Treaty, as supplemented by the Acte unique européen and as amended by the (Maastricht) Treaty on European Union of February 7, $1992,{ }^{31}$ the EC Council has some limited legislative authority for the Community. This authority does not, however, extend to recognition practice. ${ }^{32}$ Article 220 of the EC Treaty expressly contemplates recourse to treaty arrangements where recognition and enforcement practice within the Community is in question. ${ }^{33}$ Accordingly, truly bilateral negotiations between the EC and the United States respecting recognition and enforcement practices are virtually impossible. Is there then any way in which negotiations could be conducted

31. 1992 O.J. (c191) 1.

32. Perhaps the expansive reading since 1977 of Article 235 of the EC Treaty-which has been called a "necessary and proper" clause-could support the Council entering into binding negotiations, respecting recognition within the Community of non-Community judgments. See J.H.H. Weiler, The Transformation of Europe, 100 YALE L.J. 2403, 2442-47 (1991). However, this method was not used in negotiating the Lugano Convention, and, as a political matter, Community reliance on Article 235 to facilitate negotiations of a judgment convention with the United States is most unlikely.

33. See Jaques Megret et al., 15 Le Droit de la Communauté Economique Européenne, art. $220 \mathrm{cmt}$. 5, at 336-37 (editions de L'Université de Bruxelles 1987). Accordingly, the preamble of the Brussels Convention refers to Article 220 of this treaty. 
between the United States and a representative group of European states with a view to achieving a recognition and enforcement convention that ultimately would be ratified by most-if not all-of the participants?

One possibility is accession by the United States to the Lugano Convention. Under Article 62, a state that is not a member of either the EC or the EFTA can be "invited to accede upon a request made by one of the Contracting States" if the EC and EFTA member states party to the Convention "unanimous[ly] agree[]." ${ }^{34}$ Assuming an invitation were forthcoming, the United States would be interested only if, in its view, the Lugano Convention provided an acceptable recognition and enforcement regime, since presumably no part of the Convention would be open for renegotiation in connection with the accession. ${ }^{35}$

Another possibility would be to utilize the mechanisms that produced the Lugano Convention to draft a new recognition and enforcement convention for relations between the United States and the EC-EFTA member states. Technically speaking, this approach seems possible. Whether such negotiations could muster political support in the various individual nations in question is, of course, another matter.

Alternatively, the Hague Conference on Private International Law could be-and in 1992 was-asked to take up the topic of the recognition and enforcement of foreign judgments. This approach, of course, enlarges considerably the number of participants in, and the scope of, the negotiations. Negotiation could take as its starting point the Hague Convention on the Recognition and Enforcement of Foreign Judgments in Civil and Commercial Matters, ${ }^{36}$ or it could-as the United States has in fact proposed-take a new tack. ${ }^{37}$ Connecting the negotiations institutionally and substantively with the Hague Conference solves many logistical problems, focuses discussion, and facilitates the preparation of a broadly acceptable text. ${ }^{38}$

\section{Likelihood of Successful Negotiations}

Which of the possible approaches noted above is the most attractive for the United States? For a variety of reasons, the United States could not accede to the Lugano Convention even if it were invited, which is itself unlikely. Most of the exorbitant jurisdictional bases enumerated in Article 3 of the Lugano Convention violate the due process standards established by the Fifth and Fourteenth Amendments to the Constitution of the United States. ${ }^{39}$ Accordingly, the United States could not agree to enforce, as the Convention requires,

34. Lugano Convention, supra note 20, art. 62(1)(b), 1988 O.J. (L319) at 24.

35. For a discussion of whether the Lugano Convention would be acceptable to the United States, see infra notes $39-45$ and accompanying text.

36. See Hague Recognition Convention, supra note 17.

37. See discussion infra notes $41-45$ and accompanying text.

38. Another, less feasible possibility would be for the United States and other interested countries to call an ad hoc diplomatic conference for the negotiation of a Judgments Convention.

39. See Lugano Convention, supra note 20 , art. 3, 1988 O.J. (L319) at 10. 
judgments rendered in another contracting state on one of these bases against a person not domiciled in a contracting state..$^{40}$ Moreover, a treaty that entitles a contracting state to render judgments on such bases and requires the other contracting states to enforce such judgments would be deeply offensive to U.S. standards of justice and fair play.

Could the United States accept Lugano if it were amended to remove the provisions permitting exorbitant jurisdictional bases? Probably not; several other aspects of the Lugano Convention would cause the United States serious concern. A first sticking point is that the Lugano Convention-like the Brussels Convention-regulates in a complete and exclusive manner the assumption of jurisdiction as well as recognition and enforcement of judgments. While the United States would be prepared to exclude the use by contracting states of exorbitant bases of jurisdiction, and to set out certain bases of jurisdiction that, when used, would entitle the resulting judgments, in principle, to recognition and enforcement, it would resist on several grounds the complete cataloguing of the bases on which a court can exercise jurisdiction. In the first place, a state can on occasion appropriately exercise jurisdiction in situations where another state has legitimate grounds for refusing recognition to the resulting judgment. Secondly, an effort to state exhaustively the bases upon which jurisdiction can be asserted is stultifying and prevents changes in jurisdictional practice that may be needed to take into account future legal or economic developments. Indeed, such statements may even prove too limiting under contemporary conditions. Thirdly, some of the jurisdictional bases recognized by the Lugano Convention may well be either overly broad or overly restrictive, especially if the enumeration is exclusive.

In 1991, the author informally explored with representatives of the Netherlands and the United Kingdom the possibility of using mechanisms along the lines of those that produced the Lugano Convention to draft a convention for relations between the United States and EC-EFTA member states. ${ }^{41}$ It was agreed that, given the political will on the part of the EC-EFTA member states, negotiations taking the form of those that produced the Lugano Convention could be successful. However, since no institutional structure for such negotiations exists, the parties would have to work out essentially ad hoc negotiating arrangements. The representatives at these discussions devoted considerable thought to the United States's initiating negotiations for a recognition convention with the EC-EFTA. But they ultimately concluded that placing the recognition and enforcement topic on the agenda of the Hague Conference would result in negotiations more likely to reach results acceptable

40. Id. arts. $4(2), 28(4), 1988$ O.J.(L319) at $10,15$.

41. In July 1991, the author met with Japp van Rijn van Alkemade, P.A.M. Meijknecht, and F.J.A. van der Velden of the Dutch Ministry of Justice. In November 1991, he met with R.H.H. White and Nicholas Hodgson of the Lord Chancellor's Department, who were joined by Peter Beaton of the Scottish Courts Administration, Kevin Chamberlain of the Foreign and Commonwealth Office, Michael Carpenter of the Legal Secretariat to the Law Offices, and Philip Bovey and Jan Clark of the Department of Trade and Industry. 
to the United States. In Hague negotiations, the United States would not be facing the EC-EFTA member states alone, and the entire enterprise could benefit from the superb support that the Hague Conference provides.

Accordingly, on May 5, 1992, the Legal Adviser for the U.S. Department of State, Edwin D. Williamson, wrote to Georges Droz, Secretary General of the Hague Conference on Private International Law, proposing that work be undertaken by the Conference "with a view to preparing a ... [recognition and enforcement of judgments] convention ...."42 The Secretariat responded to Williamson's letter in a generally affirmative fashion. ${ }^{43}$ The U.S. proposal was discussed by a Special Commission in June 1992. The discussion led to the constitution of a Working Group that met in the Hague in October 1992 and prepared a report to assist the Seventeenth Session in deciding whether and in what form the Hague Conference should take up the topic. In May 1993, the Seventeenth Session decided to place the matter on this Conference's agenda of future work. ${ }^{44}$

CONCLUDing Reflections: Is A CONVENTION SIMPLE, DoUble, OR MIXTE TO BE PREFERRED?

\section{A. An Overview of Convention Types ${ }^{45}$}

Recognition and enforcement conventions have traditionally been conventions simples, which directly address only recognition and enforcement. Their effect on the assumption of jurisdiction is indirect and limited; judgments that do not rest on a jurisdictional basis accepted by the convention are not entitled to recognition or enforcement under the convention. By way of illustration, the Hague Convention on the Recognition and Enforcement of Foreign Judgments in Civil and Commercial Matters ${ }^{46}$ and the draft U.K.-U.S. Convention on the Reciprocal Recognition and Enforcement of Judgments in Civil Matters ${ }^{47}$ are both conventions simples.

Conventions doubles regulate both the assumption of jurisdiction and the recognition and enforcement of the resulting judgment. Such conventions set out a "white list" detailing all the bases on which jurisdiction may be predicated. All judgments resulting from such assumptions of jurisdiction automatically satisfy the convention's jurisdictional requirement for recognition and

42. Permanent Bureau, hague Conference on Private International Law (Preliminary Doc. No. 17, 1992) (for the attention of the Special Commission of June 1992 on General Affairs and Policy of the Conference).

43. Id. at 1.

44. See supra notes $4-5$ and accompanying text.

45. The basic types of judgment recognition conventions are graphically presented in Table 1 , prepared by Peter D. Trooboff, one of the U.S. experts for the Hague negotiations, and used with his permission.

46. See Hague Recognition Convention, supra note 17.

47. See Reciprocal Recognition Convention, supra note 10. 
enforcement. In its pure or complete form, the bases for the assumption of jurisdiction in a convention double are exclusive; the courts of contracting states can exercise jurisdiction in matters within the convention only if a listed basis is present. The Brussels Convention ${ }^{48}$ and the Lugano Convention ${ }^{49}$ are both conventions doubles.

The U.S. proposal to the Hague Conference is for a convention mixte. Like a convention double, a convention mixte contains a "white list" specifying approved grounds of jurisdiction. Judgments rendered in a contracting state and resting on an approved jurisdictional basis are entitled to recognition and enforcement under the convention. However, unlike a true convention double, the U.S. proposal allows contracting states to assume jurisdiction on other jurisdictional bases not listed in the convention. Judgments resulting from the exercise of jurisdiction on such bases are not assured of recognition under the convention, but a state may-unless the convention expressly provides otherwise-grant recognition and enforcement under its general law. The U.S. mixed convention proposal also contemplates a "black list" of exorbitant jurisdictional bases. With respect to matters covered by the convention, contracting states would be required to forgo exercise of jurisdiction on these bases.

\section{B. Discussion of the Merits of Convention Types}

1. Advantages and Disadvantages of These Three Types of Recognition and Enforcement Conventions. Clarity, predictability, and simplicity are best served by a convention double. By reading the convention's text, potential litigants can, subject only to possible questions of interpretation, determine at one stroke where they can sue or be sued, and the availability of recognition and enforcement for any resulting judgment.

A convention mixte similarly furthers clarity, predictability, and simplicity in two basic situations: (1) where jurisdiction could be assumed on a basis contained in the "white list," and (2) where the only jurisdictional basis available is a "black-listed" basis. In other situations, study of each potential forum's general law will be necessary to determine where a suit can be brought and whether recognition and enforcement are available under the general law of the jurisdiction where it may be sought. A convention mixte thus produces "white," "black," and "grey" zones. As to the first two zones, a convention mixte has the same potential for clarity, predictability, and simplicity as does a convention double. For "grey" zone matters, however, the situation is as muddled as that which exists in the absence of treaty regulation.

A convention simple provides significantly less clarity, predictability, and simplicity than either a convention double or a convention mixte. A convention simple only regulates the recognition and enforcement of judgments resting on

48. See Brussels Convention, supra note 18.

49. See Lugano Convention, supra note 20. 
a jurisdictional basis approved by the convention. All other issues respecting the assumption of jurisdiction and the recognition and enforcement of foreign judgments fall into a "grey" zone in which the general law of individual states controls. $^{50}$

50. A convention simple could reduce the size of this "grey" zone by providing: (1) that a judgment based on an exorbitant basis of jurisdiction cannot be recognized and enforced even if, under the general law of the state addressed, recognition and enforcement would, absent the treaty obligation, be available; or (2) that recognition and enforcement can be accorded only to judgments based on a jurisdictional basis specified in the convention. The first approach is taken by the Supplementary Protocol to the Hague Convention on the Recognition and Enforcement of Foreign Judgments in Civil and Commercial Matters. See Hague Recognition Convention, supra note 17. The second approach is rarely, if ever, encountered. 


\section{TYPES OF FOREIGN JUDGMENTS RECOGNITION CONVENTIONS}

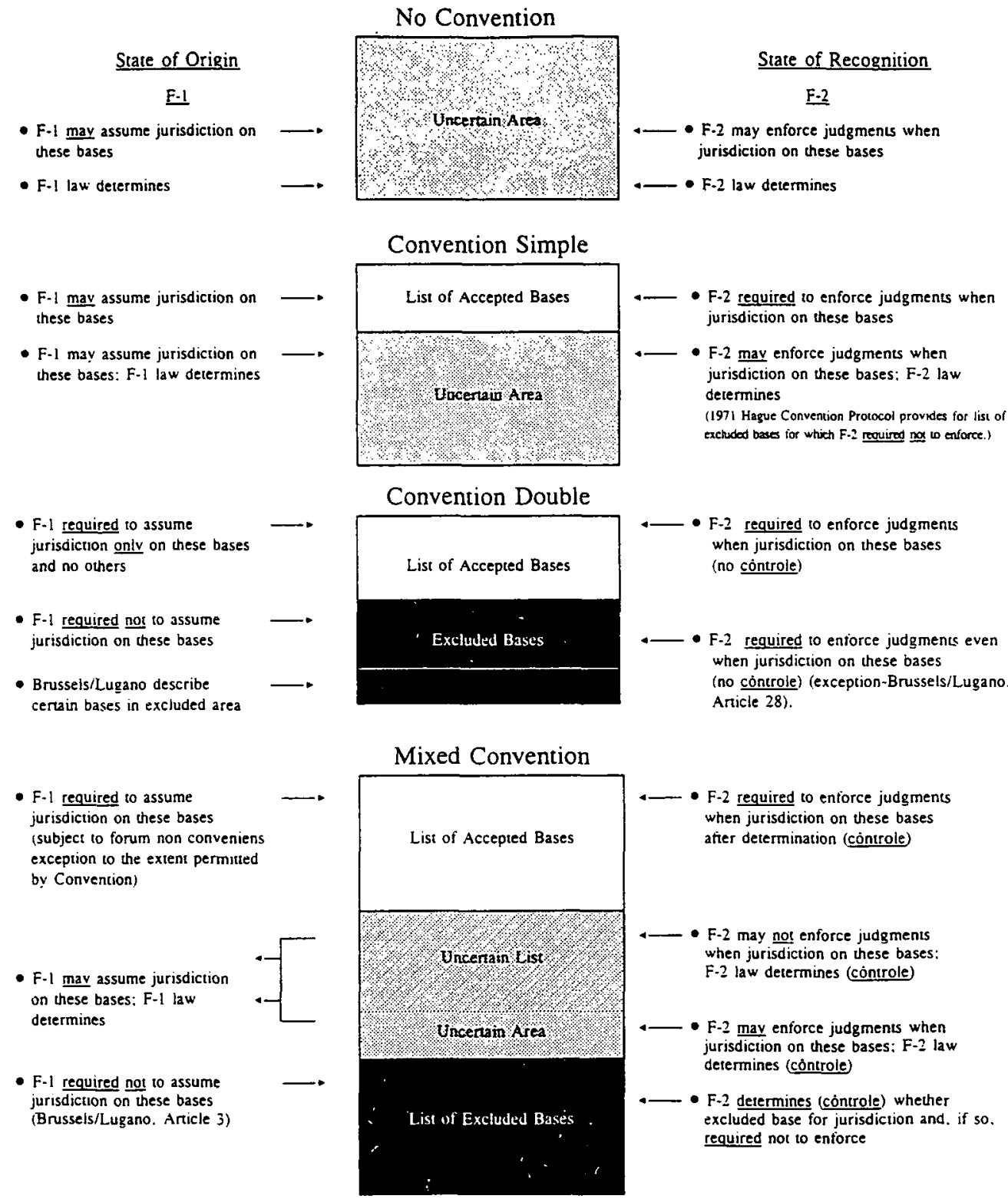

(Prepared by Peter D. Trooboff)

June. 1994 
2. Evaluation of These Three Types of Conventions from the Perspective of Litigants. Presumably, all potential litigants are assisted by having affordable information available respecting jurisdiction and the recognition and enforcement of foreign judgments. However, since they may select among the potentially available forums, plaintiffs typically value such information more than do opponents. To select wisely, plaintiffs need information on both jurisdiction and recognition and enforcement practices. Defendants have the same needs as plaintiffs for information respecting recognition and enforcement practices but, respecting jurisdiction, they need information only on the practices of the court seized by their opponent. Accordingly, clarity, predictability, and simplicity of a recognition and enforcement scheme are somewhat more important for plaintiffs than for defendants.

Plaintiffs and defendants have clearly opposed interests with respect to the availability of multiple forums. Where several forums are available, plaintiffs may choose the forum that seems most advantageous in terms of litigational convenience, expense, choice of law, and applicable procedures (for example, the availability vel non of pretrial discovery and jury trial). Consequently, plaintiffs generally prefer systems that increase the possibilities of forum shopping while defendants prefer those that reduce these possibilities.

If each of the three convention types were to contain the same, relatively restrictive jurisdictional bases, then forum shopping would be least available under a convention double and most available under a convention simple, because in a convention double, jurisdiction can only be assumed on bases set out in the convention. ${ }^{51}$

The question remains whether any particular convention form is more likely than the others to permit expansive jurisdictional bases. To the extent that a form exhibits this tendency, its use will be more likely to create a situation conducive to forum shopping. Since the "white list" of acceptable jurisdictional bases in a convention double establishes a numerus clausus, negotiators will likely strive to have included in such a convention all the bases that their respective legal systems consider appropriate. Log-rolling may then lead to acceptance of all jurisdictional bases that are supported by a significant number of the delegations. Where the assumption of jurisdiction is concerned, neither a convention simple nor a convention mixte accepts the numerus clausus principle. Accordingly, negotiation of such conventions entails significantly less pressure to accept an extensive list of expansive jurisdictional bases. Therefore, various jurisdictional bases that presumably would be included in a convention double may well be omitted in a convention simple or a convention mixte. Since

51. However, a convention double can contain provisions that facilitate forum shopping that has no legitimate justification. This proposition is clearly illustrated by the Brussels and Lugano Conventions. Both conventions not only make a series of exorbitant jurisdictional bases available against defendants not domiciled within a contracting state, but any resulting judgment must be enforced by other contracting states. See Brussels Convention, supra note 18, arts. 3, 4, 28, at 155, 161; Lugano Convention, supra note 20 , arts. $3,4,28$, at 10,15 . 
conventions simples and conventions mixtes encourage plaintiffs to rely on bases listed in the convention because these bases ensure recognition and enforcement, they discourage forum-shopping in reliance on bases that are only specified by a forum's general law.

3. A Preference for the Mixed Form. The foregoing discussion, while speculative, does suggest that a convention double may not be appropriate for use by a relatively large and diverse community of states. Such a community may well find that a convention mixte offers many of the advantages of a convention double while preserving flexibility and openness and limiting the possibilities for forum shopping.

A convention double has further shortcomings. First, the irrevocable linking of the right to assume jurisdiction with the obligation to recognize and enforce gives rise to difficulties in situations where one state can appropriately exercise jurisdiction but other states have legitimate grounds for refusing recognition to the resulting judgment. For example, when conduct in one state produces consequences in another state, the second state has a strong claim to exercise jurisdiction, but the first state may not want to recognize the foreign judgment. Second, the numerus clausus prevents changes in jurisdictional practice that may be needed to take into account future legal or economic developments. Indeed, such statements run the risk of being too restrictive even under contemporary conditions.

The convention mixte model avoids these difficulties by accepting a "grey" zone. It is easier to agree upon an acceptable "white list" for a convention mixte than for a convention double, because jurisdictional bases that a significant number of delegations consider too permissive can be relegated to a "grey" zone, which, as far as the assumption of jurisdiction is concerned, permits each contracting state to adopt for its own purposes currently utilized jurisdiction bases - and, as the need arises, to develop new bases that are neither so clearly appropriate as to be recommended for this white list, nor so clearly inappropriate as to be black-listed. The mixed model, while avoiding difficulties that inhere in the convention double model, also offers distinct advantages over the convention simple model. As already discussed, a convention mixte offers both parties significant informational advantages: a plaintiff need only consult the "white list" to know where he can sue and where the resulting judgment will be recognized and enforced. Likewise, a defendant can easily ascertain that certain exorbitant jurisdictional bases are not available to the plaintiff. Additionally, a convention mixte provides both plaintiffs and defendants with substantive guarantees respecting the assumption of jurisdiction; a plaintiff can count on the availability of certain jurisdictional bases, ${ }^{52}$ and a defendant is protected against "exorbitant" jurisdictional claims.

52. If the convention recognizes the doctrine of forum non conveniens, then this statement must be marginally qualified, since courts will be entitled in some situations to declare to exercise white-list jurisdictional bases. 
